\title{
Until the pips squeak
}

\section{Freezing the price of Medicare benefits will be more effective than the ill fated copayment}

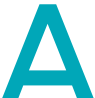
$\mathrm{n}$ amendment to our constitution after the 1946 referendum (s51 [xxiiiA]) gave the Australian Government the power to set prices for medical services. ${ }^{1}$ This amendment has often been incorrectly interpreted as the power to set doctors' fees. It is frustrating to see old misunderstandings distorting current considerations of health financing policy.

In reality, the federal government has no control over whether a doctor charges $\$ 5$ or $\$ 500$; nor to whom such a fee is charged. Doctors can charge what they choose, provided it can be justified as "fair and reasonable".

\section{Dabbling in price signals}

For the best part of a year, the health debate has swirled around a proposed copayment for general practice services. ${ }^{2}$ All the government needed to do, if it was seeking to reduce Medicare outlays on general practice services, was to reduce the price it pays for those services. That was the apparent basis for the ill fated initiative in January 2015, directed at the short consultation. Getting into an area of price signals by unnecessarily flagging a copayment simply complicates matters.

\section{"If one is used to getting a service for nothing, instituting a cost will send an eruption of squeaking pips into the political troposphere"}

When, in 2005, the government removed the disincentives for bulk-billing by allowing these services to be priced at $100 \%$ (ie, the Medicare rebate for those services was set at $100 \%$ rather than $85 \%$ ), an effective price signal was removed. This was done to serve a political agenda - to increase bulk-billing rates — which removing the price signal certainly did.

When the first attempt at codifying the doctors' various charges was made after the publication of the Nimmo report in $1969{ }^{3}$ the concept of the value of one service compared with another emerged. This then formed the basis of the prices that are set out in the Medicare Benefits Schedule (MBS). The MBS is one of the pillars of Australian health financing. Within the MBS, there is a clear scale of relativities, which means, for instance, that Medicare benefits are higher for consultations with specialists than general practitioners.

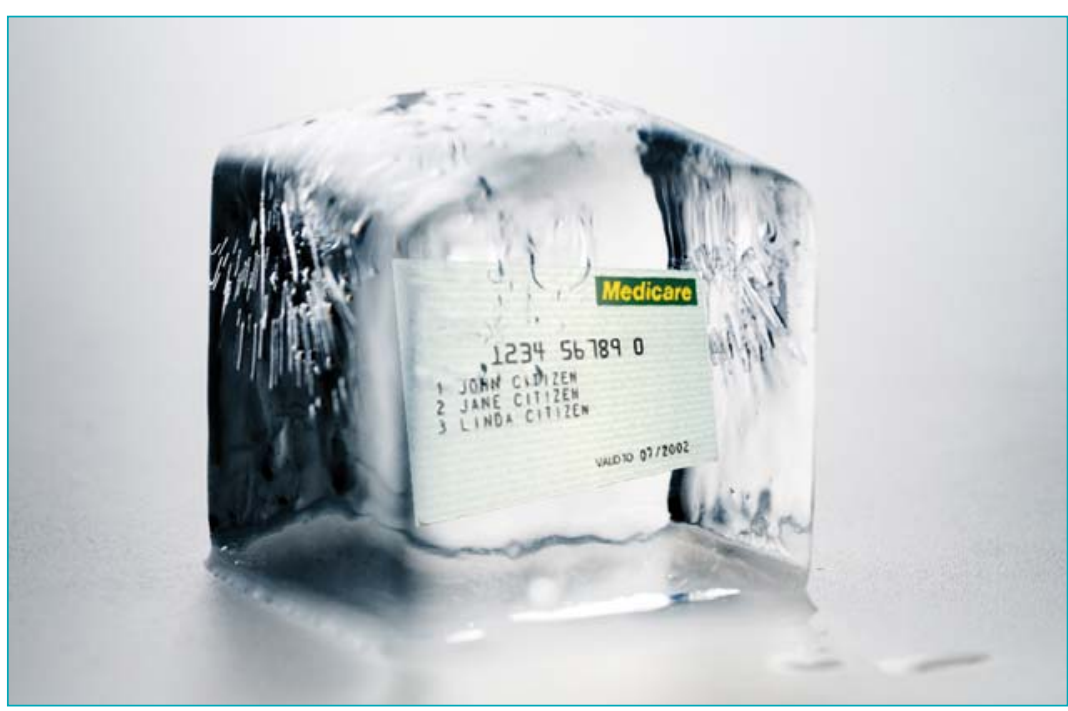

There are two factors besides the relative value of services that are considered in setting the Medicare benefit. One is the descriptor of the actual service, which defines the service. The other factor is time. Time-tiering, confined to consultation items, is used to further differentiate price. The longer the service takes, the higher the price.

One of the most controversial MBS items has always been the Level B general practitioner consultation, which is described as a consultation of "less than 20 minutes". Thus, a 2-minute consultation attracts the same benefit as a 15-minute consultation. The government, in now trying to cut costs, has belatedly recognised that the price signal for 6 minutes or less is the most profitable way of exploiting the MBS, and the current Level B consultation allows this by not establishing a minimum time.

So, the government now has the correct target for reducing costs, but the way the change was introduced in January with a Queensland election in the offing was not politically smart. It enabled all the populists, who now are rampant in federal parliament, to jump all over the decision, trumpeting how much the community will suffer. However, this is not a debate about caring for the health of the populace; it is about doctors' incomes.

\section{The Medicare price freeze}

AO, MDBS John B Best

University of Melbourne, Melbourne, VIC.

jbbest@iimetro.com.au

doi: 10.5694/mjal4.01767
As proposed and then withdrawn, the decision to reduce the price the government would pay for a Level B consultation by $\$ 20$ is a blunt instrument. However, an even blunter instrument is a price freeze on the MBS until 2018. The government could also tighten descriptors or exclude certain service items from attracting a benefit, and remove the requirement for 
prescriptions for some drugs, thus reducing the need for doctor visits.

The government can toy with copayments for consultations, but there is a "complete absence of evidence that copayments have a particularly significant quantitative effect or that they can explain even a fraction of the post-war inflation of health costs". ${ }^{4}$ In a recent issue of the Journal, Keane, lecturer in public health at Monash University, was more circumspect, but essentially agrees that there is little or no evidence that copayments work. ${ }^{5}$

The bellwether for the success of the price freeze and its selectiveness will be bulk-billing practices that depend on throughput to make profits. How far can the profit margin be squeezed before these types of "for-profit" practices have to start charging to stay solvent?

If the government is resolute, freezing the price until 2018 is the most effective way to curb Medicare outlays, especially if the general practitioner consultation descriptors are rewritten to specify an expected length of consultation. If that descriptor restricts the Level B MBS benefit to a consultation of a minimum of 15 minutes, it removes all "time" ambiguity In other words, the government price would be based on four consultations an hour. This is harder to argue against as the government has already priced a brief consultation (Level A), the price of which could be renegotiated given that no time is specified.
In the end, all the palaver about copayments is unnecessary. The government can squeeze price, and then wait until the pips squeak - especially among practices owned by private corporations. If one is used to getting a service for nothing, instituting a cost will send an eruption of squeaking pips into the political troposphere, as happened with the most recent government announcement.

A recent article made the point that "healthcare, if publicly provided, inevitably has to be constrained", but what people are fearful of is that "once the service is driven by market principles, the rationing will cease to be fair."

Wise words! The new Health Minister, Sussan Ley will need to be very wise, so intense will be the lobbying given the enormous increase in the number of vested interests.

After the fiasco in January, she promised to consult with stakeholders. Perhaps she should also look to an independent umpire, as Nimmo and his eminent colleagues were 40 years ago, when their report formed the basis of Medicare as we now know it. Sustaining a freeze over 4 years with an election in between and with a populist Senate will be nigh impossible.

Competing interests: No relevant disclosures.

Provenance: Commissioned; not externally peer reviewed. 
1 Commonwealth of Australia Constitution Act. Chapter I. The Parliament. s5l (xxiiiA). http://www.aph.gov.au/ About_Parliament/Senate/Powers_practice_n_procedures/ Constitution/ /link.aspx?_id=AE5927DE2F0148F2B8B701857 EBEB2F3\&_z=z (accessed Feb 2015.

2 Australian Government 2014-15 health portfolio budget statements. Budget Related Paper No. 1.10. Outcome 3. Access to medicine and dental services 2014. Canberra: Australian Government, 2014: 79. http://www.health.gov.au/ internet/budget/publishing.nsf/Content/2014-2015_Health_ PBS (accessed Feb 2015).

3 Commonwealth Committee of Enquiry into Health Insurance, Nimmo JA. Health insurance: report of the Commonwealth
Committee of Enquiry, March 1969. Parliamentary paper ; no. 2 of 1969. Canberra: Government Printer, 1969.

4 Richardson J. Is 8\% of the GDP enough: the future direction of Australia's health care system. Working paper 2. Melbourne: Centre for Health Program Evaluation, 1990. http://www. buseco.monash.edu.au/centres/che/pubs/wp02.pdf (accessed Feb 2015).

5 Keane M. Copayments and the evidence-base paradox. Med J Aust 2015; 202: 68-69.

6 Owen D. How to take back the NHS, before it's too late. The Guardian 2014; 1 Dec. http://www.theguardian.com/ commentisfree/2014/dec/01/david-owen-nhs-coalition2012-health-reform-act (accessed Feb 2015). 